\title{
Effects of Cooperative and Individualistic Learning Strategies on Students' Map Reading and Interpretation
}

\author{
Sunday B. Adeyemi ${ }^{22}$ and Elphinah N. Cishe \\ Walter Sisulu University \\ Directorate of Research Development \\ Nelson Mandela Drive, Mthatha Campus \\ Private Bag X1, Mthatha 5117 \\ South Africa. \\ sadeyemi@wsu.ac.za; \\ DOI//http://dx.doi.org/10.4314/gjds.v13i2.9
}

\section{Abstract}

Current conventional methods of teaching Geography in Nigeria has not improved students' performance in the subject. Hence, there is the need to expose students to other learning strategies that can improve their performance in map reading and interpretation. This study conceptualised relative effects of cooperative and individualistic learning strategies on secondary school students' achievement in map reading and interpretation. The study employs pretest, posttest, control group, quasi-experimental research design. Subjects comprised 164 senior secondary II (SSII) geography students, made up of 109 boys and 55 girls, drawn from three secondary schools in Ilesa East and West Local Government Areas of Osun State, southwest, Nigeria. Three instruments were used to collect the requisite data - Numerical Ability Test (NAT), Map Reading and Interpretation Achievement Test (MARIAT) and Treatment Implementation Guides on Cooperative, Individualistic and the Conventional learning strategies. Three null hypotheses were formulated and tested at 0.05 level of significance. Data collected were analysed using ANCOVA, Multiple Classification Analysis (MCA) and Scheffe Post-hoc Analysis. Treatment had a significant main effect on students' map reading and interpretation $[F(2,163)=35.181, p<0.05]$. Cooperative learning strategy was the most effective for the dependent measure. It was also found that numerical ability had a significant main effect on the dependent measure $[F(2,163)=16.949 ; p<0.05]$, with high numerical ability subjects performing better than their average and low ability counterparts. Results also showed that gender has no significant main effect in map reading and interpretation as revealed by table $1[F(1,163)=0.566 ; p>0.05]$. It was concluded that the cooperative learning strategy was more effective in improving students' achievement in map reading and intrpretation. Also, high numerical ability subjects performed better than those in the average and low numerical ability

22. Corresponding author: Sunday B. Adeyemi, Research Fellow, Teacher Education (Social Science). 
groups. Gender has no influence on students' achievement in map work. It was recommended that geography teachers be given on-the-job training in the use of cooperative learning strategy in classes, and that remedial classes should be organised for students with poor mathematical background. Geography teachers are enjoined to encourage students, particularly the females to show more interest in the study of geography through pieces of advice and the stimulating ways they handle the subject amongst others.

Keywords: Cognitive Theory, Gender, Learning Strategies, Map Reading, Numerical Ability

\section{Introduction}

Geography occupies an important position in the secondary school curriculum due to its usefulness to society. Through the study of geography we get to know of the world around us. These include the nature and character of our environment, the interactions between people and their environment, the consequences of these interactions between man and his environment. Others include resources available and its judicious use, preservation of the environment so as to prevent environmental degradation and other natural disasters. Through the teaching and learning of geography, certain skills, competencies, values and attitudes are developed in the students. These include reflective / Critical thinking, keen observation, accurate measurement, appreciation of the environment, patience and endurance, respect for other people's opinions all of which are crucial to man's existence on the surface of the planet earth (Adeyemi, 2002; Federal Republic of Nigeria [FRN], 2004; Mansaray, 1992).

Map reading and interpretation constitutes a crucial aspect of the study of geography, especially at the secondary school level. Fuechsel (2014) describes a map as "graphic representation, drawn to scale and usually on a flat surface of features such as geographical, geological or geopolitical of an area of the earth or of any other celestial body". Studies (Stevenson, 2011; Ogunnowo, 1990; Mansaray, 1992) agree that maps are indispensable tools for geographers at different levels. Geographers use maps in conducting studies of different geographic phenomena and in representing their findings as well. A substantial part of geographer's knowledge is recorded most accurately and most conveniently by means of maps. Fairgrieve (1951) believes that $90 \%$ of all geographic information can be put on the map.

Beside geographers, the ability to use maps is essential for intelligent living in our complex world. Maps describe every area of our lives. We use road maps, political maps, time zone maps, area code maps and street maps everyday. It is only good that every educated person should be able to recognize and appreciate the facts maps convey, (Garnett, 1971). Other school subjects which require the knowledge of map reading and interpretation include social studies, history, and economics to mention a few. 
Supporting the above viewpoint, Ory, Christophe, Fabrikant and Bucher (2015) contend that everybody who cares to live a comfortable life should aspire to be equipped with the ability to use maps intelligently, particularly as people move from one place to the other around the globe for business and tourism purposes. Therefore, the earlier students develop the requisite skills of map reading, the more comfortable they are likely to cope with some of the emerging problems in their environments. However, despite the valuable opportunities geography and map work in particular offer in our daily life, available literature (Mansaray, 1990; Adegoke, 1987) show that fewer students enrol for it as against the large number of students who opt for other social subjects such as economics, government, accounting, and business studies at the secondary school level.

This low enrolment is also evident at the University and College levels of Education. Several factors have been reported in literature to be responsible for this low enrolment in geography amongst which are wide coverage of the subject (scope), difficult topics, lack or insufficient instructional materials, inadequate qualified geography teachers, insufficient time allocated to geography on the school timetable and lack of interest on the part of the students. Other are: mathematical calculations involved in the subject (e.g. scale, bearing, measurement of gradient, cross-section drawing, intervisibility, latitude, longitude and time etc.), teacher's lack of commitment to duty, students' poor mathematical background, and the use of unsuitable methods of teaching (Mansaray \& Ajiboye, 1994; Ogunnowo, 1990; West African Examination Council [WAEC], 2012). Most of the geography teachers because of the wide scope of the subject, coupled with insfficient time allocated to the subject on the school time table, often times, resorted to the use of the lecture method in a bid to cover the syllabus. This method of teaching does not bring about active interaction among the teacher, students and the materials to be learnt. Similarly, the availability or otherwise of instructional materials in the teaching of geography, and especially map work in secondary schools, has serious implications for learning outcomes in the subject. It is either these instructional materials are inadequate or are not available for use at all. To a greater extent, the choice of a method or strategy by the teacher depends on the instructional materials available. According to Mansaray and Ajiboye (1994), there is dearth of instructional materials for the teaching of geography in secondary schools.

Consequently, the teachers resorted to the use of unsuitable methods of teaching map work in secondary schools, which did not allow for active students' participation, but only reduced them to passive recipient of knowledge. This had adversely affected the students' performance both in school and public examinations as indicated by WAEC's chief examiners' reports (WAEC,1997, 2005 and 2012). It is the use of unsuitable methods of teaching map work in secondary scools, with its attendant persistent students'poor results, that necessitated the comparison between cooperative and individualistic under 
experimental conditions to see which of them would improve students' performance in map work.

Both learning strategies have been demonstrated and found useful in other disciplines like the sciences and mathematics where they have improved learning outcomes (Herrman, 2013; Vega \& Terada, 2012; Christian \& Pepple,2012; Tsey \& Brandy, 2010; Ho \& Boo, 2007; Barkley, Cross \& Major, 2005; Ojo,1988; Alebiosu, 1998 ; Esan, 1999) in varying degrees under different tasks. In most cases, the cooperative learning strategy has been found more effective than the individualistic strategy. Johnson and Johnson (1987) in a meta-analysis involving 122 studies concluded that cooperative learning is considerably more effective than competitive or individualistic efforts. Kyndt, Raes, Lismont, Timmers, Cascalla and Dochy (2013) carried out a similar meta analysis of the "Effect of face-to-face cooperative learning: Do recent studies falsify or verify earlier findings"? Sixty-five studies were involved in this meta analysis cutting across primary, secondary and tertiary education. Result revealed a positive effect of cooperative learning on achievement and attitudes, supporting earlier findings by Johnson and Johnson (1989). Cooperative learning strategy is one in which students work together in small groups towards common goals (Slavin,1982). It has the potentials of cultivating and grooming the discipline of self-directed study, as well as learner's level of cognitive development. In the individualistic learning strategy, the student is made to work alone, interacting with the contents and learning materials (Okebukola, 1984; Ojo,1988; Alebiosu, 1998; Esan, 1999). With reference to this study, the question is: Which of these classroom structures or arrangements is likely to result in improved students' performance in map work.

The numerical ability of the subjects, that is, the mathematical background or the competence students demonstrate in calculation was considered a critical factor that could have an effect on learners' achievement in map work. Map work, which entails map reading, map analysis and map interpretation, involves a lot of calculations as are found in such topics as longitude and time, scale, measurement, bearing, gradient measurement, profile drawing, intervisibility and latitude as were earlier identified (Mansaray \& Ajiboye, 1994; WAEC, 2012). This explains why numerical ability (high, average and low) is included as one of the moderator variables.

The probable effects of gender were also investigated in the study. The decision to use gender as another critical moderating variable in this work was founded on the observation that fewer female students do enrol for geography at both the secondary and tertiary levels of the education system, painting a picture of gender sensitivity in geography, which may likely affect the results of this study. Besides, gender is a factor whose influence on students' learning outcomes has been extensively examined by researchers. Divergent reports abound in the literature on the gender issue. Okeke (2007) 
in his review of studies concluded that gender differences exist in students' achievement in science and any other subject. Studies have shown a significant difference in favour of boys (Bilesanmi-Awoderu, 2002); sometimes in favour of girls (Ogunleye, 2002) and sometimes have shown no significant difference between boys and girls in relation to their achievement and attitude in different science subjects (Okoye, 2010). Ajitoni (2007) found that there were significant difference between female and male students in terms of attitude in favour of female. Aremu and John (2005) in their study stated that the search for strategies to bridge the gap in the achievement of males and females is an ongoing one. Gender as a moderating variable, therefore, attracted further investigation in this study because of the conflicting nature of results as revealed in the above studies that focused on gender and science and science related subjects. Hypothesis 3 was therefore specifically formulated to examine the effect of gender on students' achievement in map reading and interpretation

The significance of this study is consisted in the fact that most previous studies on collaborative learning models had been largely carried out in the physical sciences, especially in chemistry and biology in the laboratory situations and perhaps in mathematics.This present study was carried out in the humanities and in a classroom situation that was largely verbal. It therefore serves as a bridge between the physical sciences and the social sciences. If found to be effective in geography, it therefore means it may equally prove effective in other subjects of the social sciences.

\section{Theoretical Framework}

The study is founded on the cognitive theory of learning. This is because the cognitive perspectives seems to have placed the value of cooperative learning in the interaction among students during group work. These interactions are seen to affect students mental processing of information to be learnt rather than their motivation to learn the material. This means that the focal point of theory is on cognitive development. Development theorists such as Vygotsky (1978) work under the basic assumption that children's interaction around appropriate tasks increased their mastery of critical concepts. Collaborative acivities among children therefore promote intellectual growth, because children of similar age are likely to function in each other's zone of proximal development, bringing about collaborative behaviours that are more advanced than each could do as individuals. This position of the developmental theorists was supported by the work of Piaget (1926) when he held that social abtriary knowledge such as language , values, rules, morality and symbol systems could only be learnt in interactions with others. Interaction, these theorists claimed is essential to logical and mathematical thought development. On this basis, developmental theorists have prescribed increase use of cooperative activities in schools. Thus, it seems likely that the cognitive processes described by developmental theorists underlie the effectiveness of cooperative learning 
in any form, motivation to help or encourage others is likely to increase the quantity or quality of peer interactions, which in turn lead to cognitive growth.

\section{Statement of Problem}

The performance of students in geography both in internal and external examinations has been on the decline. The annual WAEC chief examiners' report $(1997,2005,2012)$ has not been encouraging either. Rather, it is a confirmation of students' poor performance in geography. Map work has been identified by the report as one the most difficult aspects of geography in which students have been woefully performing. This phenomenon has constituted source of grave concern to stakeholders in educationteachers, parents, school authority, ministry of education officials, government and the society at large. Many factors, such as were earlier identified may be responsible for this worrisome situation. Therefore, as part of the continuous search to improve students' performance in geography and map work in particular in secondary schools, this current study was carried out to determine the relative effects of cooperative and individualistic learning strategies on students' achievement in map reading and interpretation, investigating the moderating influence of students' numerical ability and gender.

\section{Hypotheses}

Based on the problem stated above, the following hypotheses were formulated and tested at 0.05 level of significance:

$\mathbf{H}_{\mathbf{o}}$ 1: There will be no statistically significant main effect of learning strategies on students' achievement in map reading and interpretation.

$\mathbf{H}_{\mathbf{o}}$ 2: There will be no statistically significant main effect of numerical ability on students' achievement in map reading and interpretation

$\mathbf{H}_{\mathbf{o}}$ 3: There will be no statistically significant main effect of gender on students' achievement in map reading and interpretation

\section{Research Design and Methods}

The quantitative approach was used for the study. Quantitative research according to Lisa (2008), "is the systematic empirical investigation of observable phenomena via statistical, mathematical or computational techniques". The researcher makes use of statistics to analyse the data. A 3×3×2 pretest, posttest, control group quasiexperimental design was adopted in this study to determine the relative effects of the learning strategies - cooperative and individualistic on secondary school students' achievement in map reading and interpretation, investigating the moderating 
influences of numerical ability and gender. Dinardo (2008) describes quasi-experiment as "an empirical study used to estimate the causal impact of an intervetion on its target population. It is similar to the traditional experiental design. Quasi-experiment allows the researcher to assign the elements to treatment conditions based on some criteria". Subjects for this study consisted of 109 male and 55 female students, making a total of 164 students in all drawn from among the Senior Secondary Two (SSII) geography students in Ilesa East and West Local Government Council Areas of Osun State, Nigeria. There were twenty-one public secondary schools in Ilesa East and West local government areas, all of which offer geography. Two of the schools that are single-sex (Girls only) were excluded from this experiment due to the nature of the study that has to do with both boys and girls; while the rest nineteen coeducational schools were stratified into three zones based on their geographical locations. Three schools (one from each zone) were thereafter randomly selected by simple balloting procedure for the study. The selection of one school from each zone was done in order to control for "contamination effects". Furthermore, two intact SSII classes were randomly selected in each experimental school to participate in the study. The study was made open to all the geography students in the selected classes, and they were as such, encouraged to be actively involved in the study that lasted 9 weeks. All the participating schools and students were randomly assigned to treatment conditions of cooperative, individualistic and control group respectively.

\section{Instrumentation}

The instruments used for this study consisted of testing instruments as are found in items (i) and (ii) below and stimulus instruments as indicated in items (iii) to (v).

(i) Numerical Ability Test.

(ii) Map Reading and Interpretation Achievement Test (MARIAT).

(iii) Treatment Implementation Guides on Cooperative strategy.

(iv) Treatment Implementation Guides on Individualistic strategy.

(v) Treatment Implementation Guides on Conventional strategy.

\section{Numerical Ability Test (NAT)}

The numerical ability test is a 25-item test adapted from the Australian Council for Educational Research (ACER). There is every need for this test as it forms the basis on which subjects were classified into different numerical ability groups since the subjects' mathematical background is one of the critical factors involved in this study. 


\section{Validation of NAT}

The numerical ability test was adapted from the Australian Council for Educational Research (ACER).The reliability coefficient of the test was determined, using KuderRichardson formula $21\left(\mathrm{KR}_{21}\right)$, yielding a reliability coefficient of 0.83 .

$\mathrm{KR}_{21}=\frac{n}{n-1}\left\{1-m \frac{(n-m)}{n s^{2}}\right\}$, where;

$\mathrm{n}=$ number of items in the test;

$\mathrm{m}=$ mean of the test scores;

$S^{2}=$ square of the standard deviation of the test scores; yielding a reliability coefficient of 0.83 .

\section{Map Reading and Interpretation Achievement Test (MARIAT)}

Map reading and interpretation achievement test was designed to assess the subjects' ability to solve problems in map work. It consisted of 20 short essay questions meant to afford the students the opportunity to read, analyse and interpret the map. The levels of cognitive domain assessed by this test include knowledge, comprehension, application and analysis. This is so because the subjects need to demonstrate the factual knowledge of concepts, show evidence of understanding of the procedures involved in carrying out tasks, manifest ability to be able to read and analyse the map.

\section{Validity and Reliability of MARIAT}

The researchers determined the internal consistency of the items. The inter-rater method was employed to generate two sets of scores whose correlation coefficient (r) was computed. The reliability coefficient was calculated to be 0.89 , which was found to be highly satisfactory.

\section{Pre-Experimental Activities}

The investigator visited the schools that were selected for this study to notify them about the proposed investigation and to seek the permission of the principals and staff of the schools. This was carried out through letters that were personally delivered by the researcher to the school principals. It was done in order to solicit their support and cooperation so as to ensure the success of the study, which they gave. This was followed by holding a discussion with geography teachers in the experimental schools, with a view to making necessary arrangement for the study. Discussions were also held with geography students in the experimental schools in succession in order to acquaint them with the objectives, nature and requirements of the study. 
The participating teachers, who happened to be experienced geography teachers in their respective schools, were subjected to rigorous methodological training sessions that lasted three weeks, a week for each experimental school, as there was not enough time to bring all the geography teachers in the three schools together at once for the exercise. Nonetheless, the seven geography teachers in these schools went through intensive training especially in the use of the experimental learning strategies - cooperative and individualistic. The investigator served as the sole resource person while the training lasted.

During the training session, the teachers were familiarized with the objectives of the study. The teacher were taken through the treatment implementation guides and the lecture notes, especially on cooperative and individualistic learning strategies, as they were assumed to be sufficiently familiar with the conventional method of teaching They were also acquainted with the different stages at which the various tests could be administered on the subjects and the proper way to score and record the tests. The teachers were instructed to specifically charge the students in the cooperative groups to work and cooperate with one another in the group, that each group must always appoint a leader under the supervision of the teacher, that each group member must be able to explain any part of the problem, that each member must contribute to the solution of the problems, and that the group will be jointly rewarded based on individual team member performance, that each member receives the groups grade. The teachers during the training sessions were encouraged to ask questions, give suggestions or make observations that may enhance their understanding. During the training period, there were intervals for demonstrations of the cooperative and individualistic learning strategies in particular on selected topics.

The training session was rounded off by micro-teaching organized for each of the participating teachers to demonstrate the implementation of the experimental conditions. Three of the teachers that were adjudged the best, and who, in the opinion of the investigator displayed tremendous interest in the study were finally selected to execute the investigation. The selected experimental teachers were at the end of the training session randomly assigned to each of the experimental groups of cooperative and individualistic; and the control class respectively. The experiment lasted nine weeks, seven of which were devoted to actual treatment. While the first week was focused on the administration of Numerical Ability Test (used to determine respondents' ability levels) and MARIAT as pretest across the groups, the last week was used for the administration, grading and recording of MARIAT as posttest across the groups involved in the experiment. 


\section{Treatment}

In the cooperative experimental class, students were divided into 4-member homogenous groups of high, average and low numerical ability. Seats were arranged in such a way that facilitated interaction among members during execution of assignments. The students adjudged the best in each group for a given topic were made to lead the group in the peer-tutoring process.

In the individualistic experimental group, students' numerical abilities and gender were noted for the purposes of analysis and were instructed and seated in such a way that they could neither receive nor give any assistance from any quarter. Each worked all alone.

In the control class, the conventional classroom situation prevailed, with the teacher assisting the students when and where necessary. In the three treatment conditions, the mode of lecture delivery was held constant by the use of lecture method. Both tests (NAT and MARIAT) were administered before the commencement of treatment. NAT was administered to categorise the subjects into their numerical ability levels while MARIAT was administered across the study groups as pretest.

\section{Data Analysis}

The data collected for this study were analysed using Analysis of Covariance (ANCOVA) in which the pretest scores served as the covariate. Multiple Classification Analysis (MCA) was also used to find out how each of the groups performed while Scheffe's post hoc test was applied to show the direction of the significant differences (if any) among the groups. Hypotheses for this study were tested at 0.05 alpha

\section{Results}

$\boldsymbol{H}_{\boldsymbol{o}} \mathbf{1}$ : There will be no statistically significant main effect of learning strategies on students' achievement in map reading and interpretation. 
Table 1: Summary of ANCOVA on the posttest MARIAT scores according to treatment, ability level and gender

\begin{tabular}{|l|l|l|l|l|l|}
\hline SOURCE OF VARIATIONS & SS & DF & MS & F & P \\
\hline Covariates & 166.266 & 1 & 166.266 & 2.626 & 0.107 \\
\hline Pretest & 166.266 & 1 & 166.266 & 2.626 & 0.107 \\
\hline MAIN EFFECTS & 6194.021 & 5 & 1238.804 & 19.566 & 0.000 \\
\hline Treatment & 4454.944 & 2 & 2227.472 & 35.181 & 0.000 \\
\hline Numerical Ability & 2146.203 & 2 & 1073.101 & 16.949 & 0.000 \\
\hline Gender & 35.850 & 1 & 35.850 & 0.566 & 0.453 \\
\hline $\begin{array}{l}\text { Explained } \\
\text { Residual } \\
\text { Total }\end{array}$ & $\begin{array}{l}7919.620 \\
9180.691\end{array}$ & $\begin{array}{l}18 \\
145\end{array}$ & $\begin{array}{l}439.959 \\
63.315\end{array}$ & 6.949 & 0.000 \\
\hline
\end{tabular}

Source: Adeyemi \& Cishe (2015)

Table 1 shows the main effect of treatment on the dependent measure. Treatment had a significant main effect on map reading and interpretation - MARIAT $[\mathrm{F}(2,163)=35.181 ; \mathrm{P}$ $<0.05]$.

Based on this result, the hypothesis was rejected. Therefore, it means that learning strategies (teaching methods) greatly influenced students' achievement level in map reading and interpretation.

Table 2: Multiple classification analysis of the posttest MARIAT scores according to treatment, ability level and gender. Grand Mean = 14.293

\begin{tabular}{|c|c|c|c|c|c|}
\hline Variable category & $\mathrm{N}$ & $\begin{array}{l}\text { Unadjusted } \\
\text { Deviations }\end{array}$ & Eta & $\begin{array}{l}\text { Adjusted for Independents } \\
\text { + Covariates }\end{array}$ & Beta \\
\hline \multicolumn{6}{|l|}{ Treatment } \\
\hline Cooperative & 51 & 5.67 & & 6.12 & \\
\hline Individualistic & 56 & -6.51 & .49 & -7.10 & .53 \\
\hline Control & 57 & 1.32 & & 1.50 & \\
\hline \multicolumn{6}{|l|}{ Numerical Ability } \\
\hline Low & 62 & $-3 \cdot 50$ & & -4.11 & \\
\hline Average & 51 & .51 & .30 & .21 & .36 \\
\hline High & 51 & 3.75 & & 4.78 & \\
\hline \multicolumn{6}{|l|}{ Gender } \\
\hline Male & 109 & -1.13 & & -.34 & \\
\hline Female & 55 & -2.24 & .16 & -67 & .05 \\
\hline $\begin{array}{l}\text { Multiple } \mathrm{R}^{2} \\
\text { Multiple R }\end{array}$ & & & & & $\begin{array}{l}.372 \\
.610\end{array}$ \\
\hline
\end{tabular}

Source: Adeyemi and Cishe (2015) 
The Multiple Classification Analysis (MCA) in Table 2, gives an indication of the performance of each of the experimental groups and the control group. Students exposed to the cooperative learning strategy had the highest mean score of 20.41; the control group had 15.79 while the individualistic group had the least adjusted mean score of 7.19 .

The computed Beta scores showed further that treatment contributed the greatest proportion to the variation in the scores. Thus, treatment contributed $28.1 \%$ of the variance in Map Reading and Interpretation Achievement Test (MARIAT), the MCA table also reveals multiple R-square values of 0.372 in MARIAT.

To further search for the source of the significant differences observed among the treatment groups as indicated in the ANCOVA table, a Scheffe posthoc analysis was carried out on the mean scores of the groups in MARIAT. Table 3 presents the results of the Scheffe test

Table 3: Summary of Scheffe posthoc analysis on posttest means in MARIAT according to treatment groups

\begin{tabular}{|l|l|l|l|l|}
\hline Groups & Means & Group 2 & Group 3 & Group 1 \\
\hline Group 2 & 7.7857 & & & \\
\hline Group 3 & 15.6140 & $*$ & & \\
\hline Group 1 & 19.9608 & $*$ & $*$ & \\
\hline
\end{tabular}

Source: Adeyemi and Cishe (2015)

Legend:

*Denotes pairs of groups significantly different

Group 1: Cooperative Learning Strategy

Group 2: Individualistic Learning Strategy

Group 3: Control

Table 3 shows that the cooperative group performed consistently better than the other two groups in the dependent measure (MARIAT). Hence, the cooperative group is superior to both individualistic and the control groups, whose mean scores are 7.78 and 15.61 respectively, while the control group had the second best posttest mean score, the individualistic group had the least posttest mean score in the achievement tests. In effect, therefore, the cooperative group differed significantly from the individualistic and control groups, while the control group differed significantly from the individualistic group. 
On the strength of the result presented so far, with reference to hypothesis 1 , it is revealed that the subject differed significantly in their posttest achievement mean scores according to the learning strategies to which the groups were exposed in map reading and interpretation Achievement Test -MARIAT. The cooperative group obtained the highest posttest achievement mean score of 20.14, the control group had the second highest mean score of 15.79, while the individualistic group had the least posttest mean score of 7.19. An important aspect of the findings, however, is that the differences observed among the mean scores of the different groups were statistically significant. On the basis of this finding, hypothesis one (Ho1) was rejected.

The results demonstrated further that the cooperative learning strategy is better suited to promote higher students' performance in map reading and interpretation at the secondary school level. The control group is observed to have performed better than the individualistic group in the achievement test.

Ho2: There will be no statistically significant main effect of numerical ability on students' achievement in map reading and interpretation.

Table 1 reveals a significant main effect of numerical ability $[\mathrm{F}(2,163)=16.949$;

$\mathrm{P}<0.05]$ in map reading and interpretation achievement test (MARIAT). The results of the Multiple Classification Analysis computed for this ANCOVA revealed that the subjects in the high ability group had the highest posttest adjusted mean score (19.07), the average ability group had 14.5 while the low ability group had the least posttest adjusted mean score of 10.18 .

The Beta values showed that numerical ability contributed the second largest proportions to the $12.96 \%\left(.36^{2}\right)$ of the variance in posttest MAR1AT scores. The adjusted posttest mean scores shown above indicate that subjects in the high ability group are consistently scoring higher than subjects in the other two groups, while subjects in the average ability group follow this. The subjects in the low ability group had the least posttest adjusted mean score.

In order to probe further the direction of significant differences among the ability groups, a Scheffe posthoc test was computed on the mean scores.

Table 4: Summary of Scheffe posthoc analysis on posttest means in MARIAT according to ability level

\begin{tabular}{|l|l|l|l|l|}
\hline Groups & Means & Group 1 & Group 2 & Group 3 \\
\hline Group 1 & 10.7903 & & & \\
\hline Group 2 & 14.8039 & & & \\
\hline Group 3 & 18.0392 & $*$ & & \\
\hline
\end{tabular}

Source: Adeyemi and Cishe (2015) 
Legend:

* Denotes pairs of groups significantly different

Group 1: Low Ability

Group 2: Average Ability

Group 3: High Ability

Results in table 4 show that subjects in the high ability group with a mean of 18.03 differed significantly from the low ability group students. It may be deduced from the table that the high ability group also differs from the average ability group, and the average ability group seen to differ from the low ability group even when it is not said to be statistically significant. This fact can be noticed in the differences in the three mean scores. On the basis of these results, hypothesis 2 (Ho2) was rejected. The subjects in the high numerical ability group were shown to be superior in their performance to subjects in the other two groups in the achievement test.

Ho3: There will be no statistically significant main effect of gender on students' achievement in map reading and interpretation.

Table 1 reveals that there is no significant main effect of gender in map reading and interpretation - MARIAT $[\mathrm{F}(1,163)=0.566$; $\mathrm{P}>0.05]$. This implies that the hypothesis is not rejected for posttest mean scores in MARIAT. It, therefore, means that there is no difference in the performance of both male and female students in map reading and interpretation as demonstrated by the results in both tables 1 and 2 . The adjusted posttest mean scores calculated from table 2 are 13.95 and 13.62 for both boys and girls respectfully, and the difference between these posttest mean scores is not statistically significant.

It is also shown in table 2 that gender accounts for only $0.25 \%\left(.05^{2}\right)$ of the variations in the posttest mean scores in map reading and interpretation achievement test (MARIAT).

On the basis of these results, which showed an equivalent performance between male and female students, hypothesis 3 (Ho3) is not rejected.

\section{Discussion}

The results of the analysis of covariance (ANCOVA) confirmed that learning strategies had a significant main effect on variation in subjects' achievement mean scores in map work. The results indicated high significant main effect of treatment on MARIAT. The multiple classification analysis clearly showed that the cooperative group had a higher posttest mean score over and above the individualistic and 
control groups. This indicates the apparent superiority of the cooperative learning strategy in teaching map work in secondary schools. These findings give further empirical support to other findings on the usefulness of cooperative learning strategy over and above other learning strategies (Kyndt et al., 2013; Herrmann, 2013, Chriatian \& Pepple 2012; Vega \& Terada, 2012; Tsey \& Brandy, 2010; Ho \& Boo, 2007; Barkley et al., 2005; Alebiosu, 1998; Esan, 1999). Similarly, Johnson and Johnson (1987); in a meta-analysis involving 122 studies concluded that cooperative is considerably more effective than competitive or individualistic efforts. But on the contrary, Okebukola and Ogunniyi (1984) find out that competition was more superior to cooperative and individualistic class structures in laboratory work. Alebiosu (1998) found a significant main effect of treatment involving two cooperative learning models on the achievement of subjects in chemistry while Esan (1999) in his study found that mathematical problem-solving skills are best enhanced in a cooperative learning environment. What seems evident from these results is that the cooperative learning strategy has a great potential for effective learning of map work in classrooms at the secondary school level. This may be due to what scholars (Veenman, Kenter \& Post, 2000; Slavin, 2000) describe as task and reward structures that characterise the cooperative method of teaching. In the task structure, an individual member of the cooperative group is expected to master all aspects of the assignment or task given and be able to explain them. Members help themselves to achieve mastery where and when necessary. In other words, every member is supposed to be actively involved in the study so as to get rid of the "free rider" effect (Veenman et al., 2000). The fact that the failure of a member of the cooperative group may have an adverse effect on individuals or groups reward encourages every member of the group to be fully involved in the study. This makes the individual members to be responsible for his learning and that of his mates, giving rise to individual accountability (Johnson \& Johnson, 1994). The opportunity provided by the cooperative learning strategy whereby peer tutoring takes place makes it attractive in the teaching and learning of map work in the secondary schools. The results further showed that subjects in the control group performed better than subjects in the individualistic group. This is so because subjects in the control group could seek or give assistance to one another, in the form of giving further explanations on difficult areas. The teacher may even clarify some 'knotty' areas before the students are left on their own to provide solutions to the class assignments given by the teacher. Subjects in the individualistic group had the least posttest mean score. This is probably so because the individualistic learning structure offers less opportunity such as collorative learning and peer tutoring (Ojo, 1992), whereas cooperative learning environment requires constructive interaction among students (Johnson \& Johnson, 1987). Students in the individualistic learning group and the control class ignore the achievement striving of other students in the class. This type 
of learning environment is not likely to stimulate students towards higher achievement (Esan, 1999).

The numerical ability of the subjects was considered a critical factor that could have an effect on learners' achievement in map work. Map work, which entails map reading, map analysis and map interpretation, involves a lot of calculations as are found in such topics as longitude and time, scale, measurement, bearing, gradient measurement, profile drawing, intervisibility and latitude (Mansaray and Ajiboye, 1994; WAEC, 2012). The results of the Analysis of Covariance (ANCOVA) showed that numerical ability had a high significant main effect on the variations observed in subjects' posttest mean scores in map reading and interpretation achievement tests. It could be observed that the high numerical ability group performed consistently better in both the cooperative and individualistic groups. The results further indicated that even in the control group that was exposed to the conventional method, high numerical ability subjects performed better. However, the major finding here is that, interestingly, all the different ability groups in the cooperative group performed better than their corresponding counterparts in the individualistic and the control groups. These findings lend support to other previous findings of Okebukola (1984), Ojo (1988) and Esan (1999). These results have a more serious implication for the learning of map reading in secondary schools. The results point to the fact that students need a sound mathematical background as earlier claimed by Mansaray and Ajiboye (1994) to enable them perform well in map reading in schools.

The probable effects of gender were also investigated in this study. The decision to use gender as another critical moderating variable in this work was founded on the observation that fewer female students do enrol for geography at both the secondary and tertiary levels of the education system, painting a picture of gender sensitivity in geography, which may likely affect the results of this study. Hypothesis 3 was formulated to examine the effect of gender on students' achievement in map reading and interpretation. Results in Table 1 showed that gender had no significant main effect in map reading and interpretation, which was also corroborated by the results in Table 2. The fact that there is no significant main effect of gender on students' achievements in MARIAT corroborates the findings Alebiosu (1998), Gbodi, (1998), Akinbote, (1999) and Esan (1999). This implies that both male and female students performed equally on posttest MARIAT. In other words, the results showed that students' achievement in MARIAT is not associated with gender characteristic. These results have profound implications for students' performance in map work in geography. 


\section{Implications of Findings}

The findings of this study would have profound implications for the teaching and learning of map work in Nigeria's secondary schools. It was found that students in the cooperative group obtained significantly higher posttest mean score than those in the individualistic and control groups in the dependent measure. The cooperative learning strategy is capable of promoting discovery, which leads to the development of highquality cognitive strategies, which in turn enhances problem-solving skills. Students, regardless of their sex and ability levels, are motivated to learn, and when friendliness is established, they develop a feeling of belongingness and they are more eager to teach one another.

In order to be effective, the teacher and the students need training in cooperative learning principles, techniques and rules. Cooperative learning strategy necessitates significant role change for teachers, so they need support and guidance as they implement the skills until the strategy becomes a comfortable part of the teacher's repertoire. In the same vein, significant changes in students' attitude are required for them to learn to work cooperatively, to share ideas rather than compete for recognition and to imbibe the spirit of excitement and motivation. It is, therefore, important that the students have a clear understanding of their roles and the teachers' expectation for them as they participate in cooperative learning.

Heads of schools, curriculum planners and ministry officials should encourage and support training on how to implement cooperative learning at all levels of our education. Special workshops and short courses should be organised for teachers. Evaluation mechanisms should also be put in place to appraise the implementation process and the outcomes.

One of the findings of this study is that treatment did not interact with gender in determining subjects' scores in MARIAT. This implies that the effective use of cooperative group learning is not associated with gender characteristics. It is therefore suggested that more effort should be geared towards the popularisation of captivating instructional strategies such as the cooperative learning technique among students of the two gender groups.

Students should also be given every necessary encouragement to improve their mathematical competence as this will enhance their performance in map reading and interpretation. 


\section{Conclusion}

Consequent upon the results and discussion above, the following conclusions may be drawn:

i. That cooperative learning strategy has been found to be more effective in improving students' achievement in map reading and interpretation.

ii. Numerical ability has significant main effect on students' achievement in MARIAT.

iii. High numerical ability subjects performed consistently better than the average and low ability subjects in the dependent measure.

iv. There is still variation in the posttest mean scores of the average and low ability subjects in favour of the average ability group, even when not statistically significant.

v. It is therefore implied in these results that numerical ability wields a great deal of influence on students' map reading and interpretation.

vi. Gender has no influence on students' achievement in map reading and interpretation

\section{Recommendations}

Based on the findings of the study, the following are recommended:

In order to solve the problem of students' poor performance in map work at both internal and external examinations, the teaching/learning process should be restructured so as to accommodate new instructional strategies that will enhance students' performance. The cooperative learning strategy, which has proved effective, is hereby recommended for use. Hence, the old and stereotyped lecture method of teaching map work should be discouraged.

Geography teachers who are already in schools should be given on the job training through organised workshops, seminars and symposia where they would be exposed to all that is involved in the cooperative learning strategy.

The curricula of all Teacher Training institutions in the country should be broadened to encompass the different learning strategies that would promote effective learning.

One of the findings of this study is that students who exhibited poor mathematical background (low numerical ability) perform very poorly in map work. It is therefore 
recommended that remedial classes be organised in mathematics for students of this category to make for this numerical deficiency.

The secondary school geography curriculum should be such that would enable the teachers to identify problems, stimulate students' thinking ability, and allow for individual and group approaches to solving problems in map work.

The school authority and the teachers of geography should work together to ensure that enough instructional materials are provided for the students to enhance their learning.

\section{References}

Adeyemi, E. O. (2002). An examination of the teacher of the map works in secondary .schools. Paper presented at Ilesa, Nigeria Geography Teachers Association .Workshop.

Adeyemi, S.B. and Cishe, E.N. (2015). Data collection from the field.

Adekoge, K.A. (1987). Constraints on changing Nigerian school geography curriculum: .An .exploratory study. In M.A. Abegunde et al. (Eds). Perspectives on the senior .secondary school geography. Lagos: The Nigerian Geographical Association.

Ajitoni, S. O. (2007). An Introduction to Social Studies. Ibadan. DLC, University of Ibadan

Akinbote, R. O. (1999). Sex difference in cognitive and affective outcomes in social .studies of primary school pupils. African Journal of Educational Research, 5(1), pp. .34-37.

Alebiosu, K. A. (1998). Effects of two cooperative learning models on senior .secondary students' learning outcomes in Chemistry. Unpublished Ph.D .thesis. Ibadan: University of Ibadan.

Aremu, A. and John, A. (2005). Gender implications of the use of video drama in environmental education. In A. Dada., Akinbade and O.O. Kolawole (Eds). .Issues in language, communication and education: A book in honour of .Caroline A. Okedara. .Ibadan: Constellation books, pp. 342-352.

Barkley, E.F., Cross, K.P. and Major, C.H. (2005). Collaborative learning (online) Available at: http://serc.carleton.edu/introgeo/cooperative/whyuse.html. Accessed $18^{\text {th }}$.February, 2016. 
Bilesanmi-Awoderu, J.B. (2002). Concept-mapping, Students' Locus of Control and Gender .as Determinants of Nigerian High School Students' Achievement in Biology. Ife Psychological Association, 10 (2), pp. 98-110.

Christian M, and Pepple, T..F. (2012). Cooperative and individualized learning strategies as .Predictors of students' achievement in secondary school chemistry in Rivers State. .Journal of Vocational Education \& Technology. 9 (2), pp. 109-124.

Dinardo, J. (2008)."Natural experiments and quasi-natural experiments". The New Palgrave Dictionary of Economics, pp. 856-859.

Esan, A. O.(1999). Effects of cooperative and individualistic problem-solving Strategies on students' learning outcomes in secondary school mathematics. Unpublished Ph.D. Thesis. Ibadan: University of Ibadan.

Fairgrieve, J. (1951). Geography in schools. London University Press.

Federal Republic of Nigeria (2004). National policy on education (Rev.ed). .Lagos: Federal Ministry of Education. Fuechsel, C.F.(2014). Map / .Cartography (online). Available at: .http://global.britannica.com/contributor/Charles F. Fuechsel/1005. Accessed $.15^{\text {th }}$ February, 2016.

Garnett, o. (1971). Fundamentals in school geography. London George G. Harra .Co Ltd.

Gbodi, T.A. (1998). The effects of problem-solving strategy and lecture method on socio-cultural beliefs hindering science learning in selected junior secondary schoolsin Gwagwalada, Federal Capital Territory Abuja. Unpublished Ph.D Thesis. University of Ibadan.

Herrman, K. J. (2013). The impact of cooperative learning on student engagement: Results .from an intervention. Active Learning in Higher Education. 14 (3), pp. 175187.

Hilton, T. E. (1979). Practical geography in Africa. London: Longman Group Ltd.

Ho, F.F. and Boo, H.K. (2007). Cooperative learning: Exploring its effectiveness in .the .physics classroom (online). Available at: .http://www.ied.edu.hk/apfslt/v8 issue2hoff/ hoff10.htm\#10. Accessed: $18^{\text {th }}$.February 2016.

Johnson, D.W., Johnson, R.T., Johnson, E.H. and Roy, P. (1984). Circles of learning: Cooperation in the classroom. Alexandria, VA: Association for Supervision and curriculum Development. 
Johnson, D. W. and Johnson, R. T. (1987). Learning together and alone ( $\left.2^{\text {nd }} \mathrm{ed}\right)$. Englewood Cliffs NJ: Prentice-Hall.

Johnson, D. W. and Johnson, R. T. (1989). Learning together and alone: Cooperative, competitive and individualistic learning ( $4^{\text {th }}$ ed). Boston: Allyn \& Bacon.

Kyndt, E., Raes, E., Lismont, B., Timmers, F., Cascallar, E. and Dochy, F. (2013). A meta analysis .of the effect of face-to-face cooperative learning. Do recent studies falsify or verify earlier .findings? Educational Research Review, 10, pp. 133-149.

Lisa, M. (2008). The Sage encyclopedia of qualitative research methods. Los Angeles .Califonia: Sage Publications.

Mansaray, A. (1990). Issues in the teaching of geography for effective learning in the 6-3-3-4 educational system. In K.Onasanya and C.O.Ogunnowo (Eds). Teaching geography for optimal learning outcomes in the senior secondary schools. Nigeria Geography Teachers'Association (South Western Zone), pp. 43-63.

Mansaray, A. and Ajiboye, J. O. (1994). Topic difficulty in senior secondary school geography. Abraka Journal of Curriculum Studies, 11(1), pp. 80-92.

Ogunleye, B. O. (2002). Evaluation of the environmental aspect of the senior secondary school Chemistry curriculum in Ibadan. Unpublished Ph.D. Thesis. Ibadan: University of Ibadan.

Ogunnowo, C. O. (1990). Assessment of map work in selected senior secondary .schools in Ijebu-Ode Municipality. Nigeria Geography Teachers Association .Journal, pp. 261267.

Ojo, M.O. (1988). The differential effectiveness of cooperative, competitive and individualistic goal structures on student performance in chemistry. Unpublished Ph.D Thesis, University of Ibadan.

0jo, M. O. (1992). The differential effectiveness of cooperative, competitive and individualistic classroom interaction patterns on students' chemical problem solving skills. The Nigeria Teacher Today, 1 (2), pp. 121-129.

Ojo, T. A. (2009). Impact of Video CD and Audio Cassette Instructions on Students Learning Outcomes in some environmental education concept in Biology. Unpublished Ph.D. Thesis. Ibadan: University of Ibadan.

Okebukola, P. A. O. (1984). Effects of cooperative and individualistic laboratory .interaction patterns on students' performance in biology. Unpublished Ph.D Thesis, University of Ibadan. 
Okeke, E. A. (2007). Making Science Education Accessible to all 23rd Inaugural Lecture Series, University of Nigeria, Nsukka.

Okoye. (2010). Classroom environmental, computers and students' effective performance. An effective profile. Journal of experimental education, 62, pp. 221-239.

Omiola, M. A. Enuwa, M. R. Awoyemi, S.O and Adebayo, R. F. (2012). Effects of Blended Learning and Individualized Instructional Strategies on the Cognitive Learning Outcomes in Basic Technology. British Journal of Science, 6 (1), pp. 38-44.

Ory, J. Christophe,S. Fabrikant, S.I. Bucher, B. (2015). How do map readers recognise a topographic mapping style? (online). Available at: .http://www.tandfonline.com/doi/ abs/10.1080/ooo87041.2015.1119459?journal.code=ycaj20. Accessed $15^{\text {th }}$ February, 2016.

Piaget, J. (1926). The language and thought of the child. New York: Harcourt Brace.

Slavin, R. (1982). Effects of cooperative learning and individualised instruction on the social acceptance, achievement and behaviour of main streamed students. Report No. .327. John Hopkins University, Baltiore, MD. Centre for Social .organisation of School.

Slavin, R. E. and Hurley, E. A. (2000). Cooperative learning and achievement: Theory, research and future directions. Office of Educational Research and Improvement. US: Department of Education.

Stevenson, J. (2011). Topographic-Cartographic resources, maps and spatial data (online). Available at: http://guides.lib.udel.edu/c.php?g=85444\&p $=548756$. Accessed $15^{\text {th }}$ February, 2016.

Tsey, M. and Brandy, M. (2010). A case study of cooperative learning and communication pedagogy: Does working in teams make a difference? Journal of the Scholarship of Teaching and Learning, 10 (2), pp. 78-89.

Vega, V. and Terada, Y. (2012). Research supports collaborative learning (online). .Available at: http://www.edutopia.org/stw-collaborative-learning-research. .Accessed $18^{\text {th }}$ February, 2016.

Veenman, S. Kenter, B. and Post, K. (2000). Cooperative learning in Dutch primary classrooms. Educational Studies, 26 (3), pp. 281-302.

Vygosky, L.S. (1978). Mind in society. In Cole, M. John-Steiner, V. Scribner, S. and Souberman, E. (Eds.). Cambridge, MA: Havard University Press.

West African Examination Council (1997, 2005, 2012). Chief Examiners' reports, Lagos. 